\title{
Understanding the Nature of the Presumption of Resulting Trusts
}

\author{
Xueping Chen \\ Law School of South Central University for Nationalities, Wuhan, China \\ Email: xpchen189@126.com
}

Received 3 June 2014; revised 10 July 2014; accepted 13 August 2014

Copyright (C) 2014 by author and OALib.

This work is licensed under the Creative Commons Attribution International License (CC BY). http://creativecommons.org/licenses/by/4.0/

(c) (i) Open Access

\begin{abstract}
The nature of the presumption of a resulting trust has generated a controversy, which has created two schools of thoughts. Both schools of thoughts claim that resulting trusts give effect to the presumed intention, positive or negative. But in this paper, I take on a quite different view of point that whether a lack of intent to benefit or a positive intent to create a trust is not related with the presumption of the resulting trusts, which, I believe, will make it interesting to general readers. Further, this paper thinks the presumption of a resulting trust as circumstances or facts based on presumption, legal presumption and thinks that it can be rebutted by evidential circumstances, which are helpful to ascertain the grounds for imposing a resulting trust. In a word, exploring the nature of the presumption of resulting trusts will aid in the understanding the grounds upon which a resulting trust is imposed. This article proceeds under four parts: the role of intention in the presumption of the resulting trusts; the circumstances or facts based on presumption; a legal presumption; rebutting by evidential circumstances.
\end{abstract}

\section{Keywords}

Presumption, Resulting Trusts, Intention, Evidential Circumstances

Subject Areas: Law, Philosophy

\section{Introduction}

A resulting trust is that property returns or "results back" to the original or rightful owner or settler who becomes the beneficial owner under the resulting trust. It is as though the settler had retained a residual interest in the property, albeit created by the courts. The expression "resulting trust" derives from the Latin verb, in which result's meaning is to spring back (in effect on the original owner). Where the property is transferred subject to a condition precedent which cannot be achieved, or the creation of an express trust becomes void, or the beneficial interest is not exhausted, or contributions are made to purchase price, etc., the legal owner or transferee holds 
the property on trust for the settler (his estate), or the grantor, or the contributor.

A resulting trust is imposed by operation of law, deriving from the legal presumption. The effect on the presumption of resulting trust is that, unless rebutted, the recipient of a gratuitous transfer will hold it on trust for the transferor. When the presumption if rebutted, whether by contrary evidence or by the presumption of advancement, the recipient takes the property absolutely.

Various justificatory theories have been advanced about the nature and the grounds for imposing a resulting trust. Despite of different views on the incidence of the resulting trusts, there are two main competing unifying theories. One is that all resulting trusts give effect to the presumed intention of the transferor of property [1], described as "Swadling-Browne Wilkinson" school. The intention in this situation is positive. The other one is that the transferor had no actual intention to benefit its recipient [2], described as "Birks-Chambers" school. The intention in this situation is negative. Both are built on different opinions between these two schools of scholars. The two theories generated distinct controversies on the explanation of the incidence of resulting trusts.

Different views of the nature of the presumption of resulting trusts will lead to different views as to why resulting trusts arise. Accordingly, exploring the nature of the presumption of resulting trusts will aid in understanding the grounds upon which a resulting trust is imposed.

This article proceeds under four parts: the role of intention in the presumption of the resulting trusts; the circumstances or facts based presumption; a legal presumption; rebutting by evidential circumstances.

The role of intention: A number of legal scholars and judges have attempted to justify the imposition of a resulting trust on the grounds of intention. Whether "Swadling-Browne Wilkinson" school or "Birks-Chambers" school justify the imposition of a resulting trust on the grounds of positive or negative intention. By analyzing some cases, it can be concluded that the resulting trusts do not depend upon any evidence of what the transferor actually intended. Moreover, the parties never consciously intended to create a resulting trust because they might well never have heard of resulting trusts or might not have expected events to turn out as they did.

The circumstances or facts based presumption: Resulting trusts have not been deliberately created and arise by operation of law or, in other words, a court decision. It is up to the court to decide on the evidence whether a resulting trust arises or not. The presumption of resulting trusts is circumstances-based. The presumption of resulting trust applies, mainly relying on the circumstances or facts. If a plaintiff proves that the property is vested in the defendant alone but that the plaintiff provided part of the purchase money, or voluntarily transferred the property to the defendant, the plaintiff establishes his claim under a resulting trust unless either the contrary presumption of advancement displaces the presumption of resulting trust or the defendant presents evidence to rebut the presumption of resulting trust. In fact, all resulting trusts arising by operation of law belong to a single "irreducibly dissimilar" category of legal response. The finding of resulting law by operation of law at first owes nothing to a transferor's actual intentions. Despite its name, the idea of a presumed resulting trust does not depend upon any evidence of what the transferor actually intends. Such trusts are not inferred or implied. There is no inference of intentions made from evidence before the court. Instead they follow from the position where there is no admissible evidence of what was intended.

Legal presumption: A legal presumption provides that if a party proves a certain fact known as the preliminary fact then another fact (the presumed fact) will also be taken to be proved, unless evidence is adduced by the opponent to "rebut" the presumption. Only if the primary facts can be proved, a resulting trust can be presumed. The presumption of the resulting trust is a true and legal presumption. As a legal presumption, the presumption of the resulting trust needs to be proved by a claimant with the primary fact that the transfer or contribution was made to the benefit of the defendant that is a fixed and uniform condition. The primary facts are regarded as an evidential vehicle for the imposition of a resulting trust by the court. The transferring of the property is conceived as a fact which, along with others, calls for the creation of rights by operation of law, and saves the opposing evidences to the fact.

Rebutting by evidential circumstances: The content of the presumption of a resulting trust is that a resulting trust arises in the first place from the gratuitous or voluntary transfer or purchase of property in another's name or joint names in the absence of clear evidence to the contrary. As mentioned above, the presumption of resulting trust is irrelevant to the intention of parties. The presumption of resulting trust is just that the transferee is presumed to hold the property on trust for the transferor or the purchaser, which is made from some facts and sometimes needs to be evidenced. The presumption of a resulting trust is occasionally displaced by evidence of the contrary facts or a counter-presumption of equity, that is, the facts for presumption can be rebutted by the evidences to the contrary and by the strength evidences adduced. The evidential circumstances of the actual case 
can rebut the initial conclusion of the presumption by operation of law. The presumed resulting trust arises from numerous fact situations which are actually very different, and thereupon the evidential circumstances of rebutting the presumption are also different.

\section{The Role of Intention in the Presumption of the Resulting Trusts}

Resulting trusts arise in order to fill a gap of ownership and come into existence whenever there is a gap in beneficial ownership. Resulting trusts operate to fill the gap in the beneficial ownership of property where an express trust fails. The presumed resulting trust also arises, in the absence of evidence to the contrary, when property is purchased in the name of another, or property is voluntarily transferred to another e.g. A purchases property which is conveyed in the name of B, or A transfers property to B. In these circumstances B prima facie holds the property on trust for A [3].

A presumed resulting trust is a prima facie rule of evidence which is capable of being rebutted. When there is no definitive evidence in the first place concerning the transferor's real intention, but merely a purchase of property or the voluntary transfer of property in the name of another, equity prima facie considers the transferee as a trustee for the transferor. In short, the transferee is presumed to obtain a nominal interest in the property. The rule is arbitrary but the presumption has the advantage of determining the ownership of the beneficial interest, subject to evidence to the contrary [4]. In general, in a presumed resulting trust the destination of the beneficial interest is unclear on the face of the instrument affecting the transfer. In an effort to reduce the element of doubt concerning the beneficial interest the court implied or presumed a trust in favor of the transferor. The rationale behind this principle is that Equity is inclined to lean against a gift.

A number of legal scholars and judges have attempted to justify the imposition of a resulting trust on the grounds of intention. Whether "Swadling-Browne Wilkinson" school or "Birks-Chambers" school justify the imposition of a resulting trust on the grounds of positive or negative intention. In his work, William Swadling claimed that resulting trusts were imposed on grounds that the transferor of property intended to create a presumed intention resulting trust [5]. His work was very much influential in Lord Browne-Wilkinson's judgment in Westdeutsche Landesbank Girozentrale v Islington LBC, where it has already been observed that the House of Lords held that a resulting trust responds to the presumed intention of the person transferred property. In Westdeutsche Landesbank Girozentrale v Islington London Borough Council, Lord Browne-Wilkinson stated that resulting trusts arise to fulfill the implied intentions of the parties: "Both types of resulting trust are traditionally regarded as examples of trusts giving effect to the common intentions of the parties. A resulting trust is not imposed by law against the intentions of the trustee (as is a constructive trust) but gives effect to his presumed intention" [6].

In Standing v Bowring (1885) 31 Ch D 282, the court explained that "trusts are neither created nor implied by law to defeat the intentions of donors or settlers; they are created or implied or are held to result in favor of donors or settlers in order to carry out, and give effect to their true intentions, expressed or implied" [7]. As for this, if a resulting trust is imposed on the grounds of donors or settlers' intention, can there be any difference between an express trust and a resulting trust? Not at all.

An express trust is created on the intentions of donors or settlers, called "intentional trusts" because the settler by effectively exercising his powers to create a trust has produced what he intended. The intention plays an important role in the creation of express trusts. A trust can be known as an express trust just owing to its creation on the deliberate intention and act of the settler, when he effectively exercises his powers of ownership to create a trust [8]. Thereupon the first requirement of the creation of an express trust is that there is an intention on the part of settler to create a trust. It is an express trust that arises in response, and to give effect, to the intention to create a trust, so without such an intention there is clearly no basis for finding an express trust. What matters is the substance of intention and not the form such as the language used to express that intention. As Megarry J put it in Re Kayford Ltd (1975) 1 WLR 279, "it is well that a trust can be created without using the words 'trust' or 'confidence' or the like: the question is whether in substance a sufficient intention to create a trust has been manifested." Thus, the settler must demonstrate his or her intention either through the language used, or by his conduct that he intended to create a trust. In Staden v Jones, the Court of Appeal emphasized that in creating a trust, words or acts done by the settler must have intended to have that meaning. Therefore, an express trust arises out of the settlers' or grantors' express intention. Subject to any formalities imposed by statute, this intention may be expressed wholly or partly, orally or by conduct or in writing. In order to ascertain the terms of the 
trusts (such as the beneficiaries and their interests, the trust property and the trustees) the court is required to construe the evidence which manifests the intention of the creator of the trust. If a transferor's actual intention can be discerned, it may be that an express trust is established, on the basis of sufficient evidence that this was what the transferor actually intended, for it will have been the transferor's actual and sufficiently manifested intention to create a trust in this way, not anything else. The effect to this intention is that an express trust will have been declared. Moreover, usually doubtful words or precatory words can create a trust if they satisfy three certainties, and they are express, declared trusts. Thereupon, the court concludes that the settler sufficiently manifested an intention to declare the trust based on the evidence available. If a resulting trust arises by virtue of the unexpressed or implied intention of the settlers or grantors, "unexpressed or implied" intentions can be proved by conduct or doubtful words or precatory words so that the conduct or doubtful words or precatory words can convert the intentions into express intentions of settlers or grantors. As such, the idea that a resulting trust responds to the intentions of the parties obscure the bordering of an express trust and a resulting trust.

However, in some situations where a resulting trust arises, property will be regarded as subject to a trust despite the absence of any express intention on the part of the settler. In fact, in those situations a settler creates a trust without intending to do so at all. Moreover, in certain circumstances the resulting trusts arise by operation of law, imposed by law, which is to say that the law itself creates an equitable title for beneficiaries in the property of a legal owner, [9] not that the parties intend to create a resulting trust. William Swadling advocated that presumed resulting trusts are ones that the presumed intention is operative to create a trust, which is proved by the application of an evidentiary presumption, that is, a legal presumption of fact [10]. Just as Chamber argues that a number of different cases where a presumed resulting trust arose simply cannot be explained on the basis that the law rebuttably presumes an intention to create a trust, since in these cases the evidence established that the transferor or contributor had no such intention and yet the trust arose anyway. Take "The Venture" [11] for example, The plaintiff, Percy Stone, proved that he had contributed to the purchase price of a yacht, title to which was transferred to his brother, Andrew, who had since died. A resulting trust is imposed for Percy depending upon the bare fact of Percy's contribution. Farwell LJ, giving judgment for the Court of appeal, held.

When it is once proved that Percy Stone advanced $£ 550$ of the $£ 1050$ purchase-money for this yacht he thereupon became entitled to fifty-five 105ths. That being the presumption, it was, of course, open to the other side to displace that presumption, but it was not incumbent upon Percy Stone to prove more than that. It was for the other side to displace that presumption if they could, but they offered no evidence at all [12]. In this case, a resulting trust is operated by law, which was not established on the intention of the parties at all.

The case of Mehta Estate v. Mehta Estate taken into consideration, a husband had purchased certain investments in the name of his wife, but again there was no proof of the intentions of the husband, or his wife, as both had perished in a plane crash. There is no need to show whether there was an intention or not.

In Vandervell v IRC (1967) 2 AC291, the facts clearly show that there was a complete absence of intention, real or presumed. In this case, Vandervell transferred an option to purchase shares from the Royal College of Surgeons to a trust company without defining the benefactors of that option, the court held that the option belonged to Vandervell under a resulting trust. Indeed the only intention of Vandervell was to divest himself of any interest in the property being transferred, no intention to a resulting trust.

Also in Re Vinogradoff (1935) WN 68, a testatrix transferred $£ 800$ worth of a war loan into the joint account of herself and her granddaughter of then four years old. The testatrix continued to receive the dividends on the loan until her death. On her death the court held that the granddaughter held the war loan on resulting trust for her grandmother. There is nothing on these facts to suggest that the intentions of the grandmother were to make her granddaughter a trustee of the property she had transferred in their joint names.

In Air Jamaica v Charlton (1999) 1 WLR 1399 (PC), when a company pension fund was wound up, its contributors argued for a return of their outstanding contributions, even though they had received their expected entitlement. In this case, Clause 4 of the trust deed stated that no moneys which had been contributed by the company shall in any circumstances be repayable to the company. Under Section 13 of the pension plan the company could end the plan at any time and the court stated that this had in fact happened. The provisions of the pension plan trust deed which covered what should happen to any surplus in this event were void as infringing the rules against perpetuities. In this case, a resulting trust arose in favor of the contributors, with the association members as its trustees. Lord Millett explained the basis for the imposition of the resulting trust in the face of clause 4 of the pension scheme was an absence of intention to pass a beneficial interest on the part of the transferee. Although Lord Millett's approach was further applied by him in Twinsectra Ltd v Yardley (2002) 2 All 
ER 377, the Court of Appeal in this case was clearly of the opinion that the beneficial interest under a Quistclose trust remained in suspense until the stated purpose of the loan has been carried out or had otherwise failed. This view was rejected in the House of Lords on the grounds that it did not fit comfortably with established principles of equity "equity abhors a beneficial vacuum" and that the beneficial interest in property must belong to some person at all relevant times. In essence, Lord Millett's approach is strained with the negative intentions of parties. Whether in Air Jamaica v Charlton or in Twinsectra Ltd v Yardley, the imposition of the resulting trusts were irrelevant to the intentions of parties, positive or negative, not as decisive as to the ownership of the beneficial interest as that on the creation of an express trust. A resulting trust is different from an express trust in that the parties involved do not knowingly and intentionally create a resulting trust. Therefore a resulting trust arises "by operation of law."

In the work, Lewin on Trusts, Mowbray categories resulting trusts as arising by operation of law [13]. "Trusts arising by operation of law are trusts which are not declared by any person, either by clear or doubtful words" [14] Not as in an express trust, the parties involved do not knowingly and intentionally create a resulting trust. As a matter of logic, the presumption that the recipient or transferee should hold the property transferred gratuitously on trust for the transferor is just a legal consequence of a legal operation, rather than a legal recognition of the effectiveness of an individual's sufficiently manifested in respect of the disposition of his own property. Resulting trusts don't arise from such a recognition, or from any inference from evidence actually of both parties' intentions before the court. Just as Lord Diplock described in Petitt v Pettitt [15]:

"Imputing an intention to a person whenever the intention with which an act is done affects its legal consequences and the evidence does not disclose what was the actual intention with which he did it ... A presumption of fact is no more than a consensus of judicial opinion disclosed by reported cases as to the most likely inference of fact to be drawn in the absence of evidence to the contrary."

As such, it is greatly an operation of law, in the absence of evidence to the contrary. It is clear that the presumption of fact described here is not one made from evidence before the court of the actual intention of the particular transferor concerned. It is an imputation onto the known facts drawn from the court's experience. The presumption from the facts and circumstances or events can resolve the matter, rather than the inference arising only in the absence of the evidence that does not disclose what was the actual intention of the transferor. Such trusts do not depend upon any evidence of what the transferor actually intended. Moreover, the parties never consciously intended to create a resulting trust because they might well never have heard of resulting trusts or might not have expected events to turn out as they did [16].

\section{The Circumstances or Facts Based Presumption}

Why the proprietary interest has "jumped back" to the transferor when a resulting trust arises?

Resulting trusts have not been deliberately created and arise by operation of law or, in other words, a court decision. It is up to the court to decide on the evidence whether a resulting trust arises or not.

Equity abhors a beneficial vacuum. It is just in response to injustices arising from ownership of property. A resulting trust arises from the circumstances in which the ownership of property will not be clear because a transfer of property has failed or is incomplete, or because a group of people have contributed to the acquisition of that property without allocating title clearly. In such situations, the doctrine of resulting trusts operates to resolve those questions of ownership. Accordingly, where a settler conveys or transfers property to trustees, but fails to declare the trusts upon which it is to be held; or where the expressed trusts fail altogether on the ground, for instance, of uncertainty, or non-compliance with statutory requirements as to writing; or where they fail partially on similar grounds, or because the trusts expressed only dispose of a part of the equitable interest; in any such case the entire equitable interest, or such part thereof as has not been effectively disposed of, remains vested in the settler or, in technical language, is said to result to him, and the property is accordingly said to be held by the trustees upon a resulting trust for him.

The presumption of resulting trusts is circumstances-based. The presumption of resulting trust applies, mainly relying on the circumstances or facts. If a plaintiff proves that the property is vested in the defendant alone but that the plaintiff provided part of the purchase money, or voluntarily transferred the property to the defendant, the plaintiff establishes his claim under a resulting trust unless either the contrary presumption of advancement displaces the presumption of resulting trust or the defendant presents evidence to rebut the presumption of resulting trust. Therefore, in cases where the presumption of advancement does not apply, a plaintiff can establish 
his equitable interest in the property [17].

In the situation where property is purchased in the name of one person, but two people have in actual fact contributed to the purchase price of the property, the legal owner of the property will be viewed as holding the property on trust for themselves and also for the other person who contributed to the purchase price. In the scenario the beneficial interest in the property can be seen to revert to the persons who contributed to its purchase, a resulting trust comes into being properly.

Wherever a gift of personal property is made, the presumption will be made in equity that the gift is to be held on resulting trust for the person making that gift, in the absence of clear evidence to the contrary. The idea is to protect the more vulnerable against those who would take advantage of gifts. In Fowkes v. Pascoe (1874-1875) LR 10 Ch App 343: Those that allege that other people, especially in this position, give them large sums of money, must prove it, and prove it to the satisfaction of a Court of Justice that they are entitled to that sum of money. For example, if A legally transfers property to B and receives nothing in return, unless there is evidence to rebut, namely to prove it is a gift, it is presumed that $\mathrm{B}$, who holds the property legally, hold it on resulting trusts for $\mathrm{A}$, who has the equitable interest. It is based on the deep-seated idea in the law that someone must give consideration, something of value, in return to gain any right to property. An equitable maxim says, "Equity will not assist a volunteer." A volunteer is someone who has not given consideration. The idea that sensible inferences may be drawn from all the circumstances is the approach taken nowadays: In reality the so-called presumption of a resulting trust is no more than a long stop to provide the answer when the relevant facts and circumstances fail to yield a solution (Vandervell v IRC (1967) per Lord Upjohn; see also Pettit v Pettitt (1970); McGrath v Wallis (1995)) [18].

In some situations, people are unable to prove the actual, intentional arrangement that was supposed to give them an interest. The only evidence one needs to take advantage of the evidentiary presumption is evidence that one contributed to the purchase price of property.

In Dyer v Dyer (1788) 2 Cox Eq Cases 92 [19], Simon Dyer had bought property in Wiltshire jointly in the names of himself, his wife and younger son. Mr Dyer had paid the whole of the purchase price for the property. On the death of Mr Dyer, his elder son argued that the property should be held on resulting trust for the estate of the father because he had put forward the whole of the purchase price for it. This would have meant that the son would have benefited from the property as one of the heirs to his father's estate. However, the court found that the purchase had been a gift in favor of the wife and younger son and that there was therefore no resulting trust in the father's favor on basis of the presumption of advancement in favor of the father's wife and child. In this case, Eyre CB stated "the trust of a legal estate, whether freehold, copyhold, or leasehold; whether taken in the names of the purchasers and other jointly, or in the names of others without that of the purchaser; whether in the one name or several; whether jointly or successive-results to the man who advances the purchase-money”. And the parties' relationship is a fact which is relevant to the application of the presumption of resulting trust.

In Vandervell v IRC [20], there was a complete absence of intention, real or presumed, just the facts of this case clearly show that that any beneficial interest in shares was held by a settler, Vandervell, which he was transferring to the Royal College of Surgeons, and he held the subsequent option to purchase those shares which were eventually held by the Vandervell Trust Company for the benefit of his children. Indeed, the only intention of Vandervell was to divest himself of any interest in the property being transferred. In fact, Vandervell would seem to have formed no relevant intentions about the destiny of any beneficial interest in the option. When Vandervell transferred an option to purchase shares from the Royal College of surgeons to a trust company without defining the benefactors of that option, the court held that the option belonged to Vandervell under a resulting trust [21]. If Vandervell' actual intention were sufficient to be evidenced, the option should be held on an express trust, instead of a resulting trust.

In Re Vinogradoff, where a testatrix transferred $£ 800$ worth of a war loan into the joint account of herself and her granddaughter who was then four years old. The testatrix continued to receive the dividends on the loan until her death. On her death the court held that the granddaughter held the war loan on resulting trust for her grandmother. There is nothing on these facts to suggest that the intentions of the grandmother were to make her granddaughter a trustee of the property she had transferred in their joint names. The court imputed a resulting trust just on the grounds of the transferring fact.

These cases reveal the general principle that a presumption of resulting trusts in favor of someone depends upon some facts, such as paying the purchase-money for a transfer of property to another, not parties' intention. These can also evidence that a resulting trust is just from the legal presumption not depending upon the parties' 
intention, at least when arising of it. Just as Robert Chambers argued, "If the resulting trust was created by the presumed intention that it should exist, it could not properly be applied whenever that intention was impossible, improbable, or unenforceable" [22]. But next, Robert Chambers made a self-contradictory argument: "The presumption of resulting trust and advancement are inferences of the provider's intention and it is lack of his or her intention to benefit the recipient which attracts the resulting trust itself.” By reference [23] to all relevant facts and circumstances, the matter can not be determined, it can resort to a resulting trust which is expressed in terms of a presumption of a trust for the transferor. As such, the law assumes that a resulting trust will be imposed on any unconscionable circumstances.

Although Dr. Chambers insists that resulting trusts do not depend upon an implied intention to create a trust, he insists that the provider of property did not intend to benefit the recipient. This in fact admitted that resulting trusts depend upon an implied negative intention to create a trust, because the transferor's intention is relevant to demonstrate that there was no intention to benefit the recipient.

In fact, all resulting trusts arising by operation of law, belong to a single "irreducibly dissimilar" category of legal response. The finding of resulting law by operation of law at first owes nothing to a transferor's actual intentions. Despite its name, the idea of a presumed resulting trust does not depend upon any evidence of what the transferor actually intended. Such trusts are not inferred or implied. There is no inference of intentions made from evidence before the court. Instead they follow from the position where there is no admissible evidence of what was intended [24].

In the leading case Vandervell v IRC, Lord Upjohn argued that "if the beneficial interest was in A and he fails to give it away effectively to another or others or on charitable trusts it must remain in him" [25]. So in this case, the beneficial interest not being transferred effectively to another or others or on trust is just a fact or circumstance, which doesn't mean that the transferor has the implied intention to create a trust or not to benefit the transferee. Moreover, "the equitable, or beneficial interest, cannot remain in the air: the consequence in law must be that it remains in the settler" [26]. hambers thought, "The interest which the settler has at the end of the story, as a beneficiary of a resulting trust, is an equitable interest which is different from the legal ownership he or she had at the beginning” [27]. Just as Lord Browne-Wilkinson remarked,” A person solely entitled to the full beneficial ownership of money or property, both at law and in equity, does not enjoy an equitable interest in that property. The legal title carries with it all rights. Unless and until there is a separation of the legal and equitable estates, there is no separate equitable title” [28]. And it is also subject to Swadling's significant criticism.

Mellish LJ in Fowkes argued: If there is evidence to rebut the presumption, then... the Court must go into the actual facts. And if we are to go into the actual facts, and look at the circumstances of this investment, it appears to me utterly impossible... to come to any other conclusion that that the ... investment was made for the purpose of gift and not for the purpose of trust. It was either for the purpose of trust or else for the purpose of gift; and therefore any evidence which shows that it was not for the purpose of trust is evidence to show that it was for the purpose of gift.

In fact, in the case of Fowkes, whatever purpose was the investment made is nothing significant for the presumption of the resulting trust, the presumption was made from the actual facts and the circumstances of the investment. The courts draw a presumption from the presence of other facts (namely, a gratuitous transfer between parties in a certain relationship to one another). A particular fact is presumed which leads to the conclusion that a resulting trust has arisen. It is the facts that justify a finding of a trust of the property transferred. The justifiability of particular presumptions depends upon the facts.

In Re Vinogradoff (1935) WN 68, the presumption of a resulting trust depends upon the fact of the gratuitous transfer. Accordingly, the court held that the presumption of resulting trust had not been rebutted, and so the child held the property on trust for the grandmother.

In Vandervell v Inland Revenue Commissioners (1967) 2 AC 291, 313, the presumption of a resulting trust is justified by the mere facts of the transfer and the parties' relationship except for further evidence beyond the facts.

In the Pettitt v Pettitt (1970) AC 777, the presumption of advancement applies in light of the facts of transfers by fathers to their children and by husbands to their wives, certainly not where a mother transfers property to her children or a wife to her husband.

\section{Applying the Presumption of Resulting Trust Is a Legal Presumption?}

In the Shorter Oxford English Dictionary, a presumption is defined as "The taking of something for granted; al- 
so, that which is presumed; assumption, assumed probability, supposition, expectation" [29]. On the basis of the basic fact, we assume the presumed fact. The assumption of the truth of anything until the contrary is proved.

\subsection{Explanation of the Concept of a Legal Presumption or a Presumption of Fact}

A true presumption should prove the primary facts until the contrary is proved. In law, there are presumption of facts and presumption of law.

The presumption of facts is that circumstantial or presumptive evidence consists of proved facts from which a disputed fact is sought to be inferred; when a similar set of facts has repeatedly given rise to the same conclusion, the inference is called a presumption of fact. The facts proved must obviously be relevant to the disputed fact [30]. The presumption of facts involves the ordinary process of logical inferences or judicial reasoning about facts [31]. So-called presumption of facts is not true presumption, being, in reality, nothing more than common-sense inferences drawn from what is usually circumstantial evidence. It is not a true presumption because there is no requirement that the tribunal of fact adopts the presumption and assume the presumed fact once the preliminary facts are established, any more than there is for any other type of telling circumstantial evidence. It serves to direct the tribunal of fact to possible inferences that might be drawn from the evidence [32]. A presumption of facts is invariably rebuttable. Where a presumption of facts applies, on the proof or admission of a fact, another fact may be presumed. But unlike rebuttable of law, a presumption of facts does not shift the persuasive or evidential burden. Strictly speaking, the term "presumption of facts" is a misnomer. It describes the readiness of the court to draw certain repeated inferences as a result of common human experience [33].

A presumption is a rule of law which provides that if a party proves a certain fact (known as the preliminary fact) then another fact (the presumed fact) will also be taken to be proved, unless evidence is adduced by the opponent to "rebut" the presumption, or, in other words contradict the presumed fact [34]. Legal presumption can be divided into two types: "persuasive" and "evidential". Some presumptions are termed as "persuasive" or "compelling" in that once the primary fact has been proved, the presumed fact can only be rebutted by adducing evidence to the appropriate standard of proof. Other presumptions are classed as "evidential" or "provisional" in that they may be rebutted by adducing evidence sufficient to amount to a prima facie case [35]. As to the former, for example, once a child is proved to have been born in wedlock, it is presumed to be legitimate unless the other side prove non-access or incapacity by the husband; or when two people die at about the same time, the younger is presumed to have survived the elder, unless it is proved that the elder survived the younger. As to the latter, the presumption that the testator was of testamentary capacity, the relevant fact or circumstance is often said to raise a "presumption" or "prima facie" case. The presumption of legitimacy is a persuasive legal presumption. The presumption of legitimacy provides that, once it is established that a woman was married at the time that her child was conceived or born, the child is presumed to be the offspring of her husband. Where the presumption operates, it creates a legal presumption, so that once it comes into operation, the opposing party will have to rebut the presumption on the balance of probabilities. The presumption of death is a evidential legal presumption. The presumption of death needs to prove three primary facts as following: a) that no acceptable evidence exists that the person has been alive during a continuous period of seven years or more; $b$ ) that person who are likely to have heard from him during that period have not heard from him; and c) all due inquires have been made to locate the subject but those inquires have failed.

The difference between a presumption of law and a presumption of fact in the following respects [36]:

1) A presumption of law derives its force from law, while a presumption of fact derives its force from common sense and logic. However, many of the former have intrinsic logical weight, being indeed derived from the latter, yet there are others which have none. Thus, after a person has been absent for six years and 364 days there can be no presumption of death, yet the addition of one more day's absence will enable the presumption to be applied.

2) A presumption of law applies to a class the conditions of which are fixed and uniform; a presumption of fact applies to individual cases, the conditions of which are inconsistent and fluctuating. Thus, the presumption of death arises whenever seven years; unexplained absence is proved; but when it is necessary to establish the time of the death more precisely, the question must be decided on the evidence adduced in each specific case.

3) A presumption of law is made by the court, and in the absence of opposing evidence is conclusive for the party in whose favor it operates and for the purpose for which it operates; a presumption of facts results in inferences drawn by the tribunal of fact, who may disregard them, however cogent. 


\subsection{The Presumption of Resulting Trust Is a True Presumption and a Legal Presumption}

Resulting trusts arise in some contexts. One is arising where some attempted disposition of that property has failed, such as the failure to declare a trust, the failure of the trust, the failure of a specific purpose, whose function is either to restore the equitable title in property to its previous beneficial owner, or to recognize that such title remains with that person in equity. Another is arising where one person have provided a property to others from the absence of consideration and any presumption of advancement, such as voluntary conveyance or transfer, purchase in the name of another, whose purpose is to prevent others from seeking unconscionably to deny the proprietary rights of the providers of the property, which is used by equity to resolve situations in which the parties' intentions cannot be proved conclusively [37]. Another is arising where a trust has been performed and a surplus remains, such as maintenance surplus, disaster fund surplus, unincorporated associations' dissolution surplus and pension fund surplus, whose desirability of the resulting trust can depend on the context in which the trust is created [38]. In the first scenario, it is called an automatic resulting trust, because of that failure that the property, being unable to stay with the trustees and having nowhere else to go, automatically reverts to the original owner of the property, while in the next two scenarios, they are called presumed resulting trusts, which arise on the grounds of some particular facts or circumstances.

\subsubsection{True Presumption}

Just as William Swadling claimed that some presumption is not true presumption, the presumption of innocence is not a true presumption, just a basic procedural rule allocating the incidence of the burden of proving the basic elements of a crime to the prosecution in criminal cases, without need to prove the primary facts [39]. But the true presumptions differ from that. S.184 of the Law of Property Act 1925 provides that where two or more persons have died in circumstances rendering it uncertain which of them survived the other, such deaths shall be presumed to have occurred in order of seniority, and accordingly the younger shall be deemed to have survived the elder. The presumption of the order of the death of the seniority is a true presumption, in which the proof of the basic fact is conclusive proof of the truth of the presumed fact. The presumption of legitimacy is also a true one that the proof of the basic fact is sufficient to establish the truth of the presumed fact unless the other party can prove, to the requisite standard of proof, that the presumed fact is untrue. The effect of a true presumption is that if the basic fact is proved then this casts onto the other party the burden of adducing evidence in order to show that the presumed fact is untrue [40].

The presumption of resulting trust is definitely a true presumption, which is deriving from that a primary fact is proved. A resulting trust will be presumed if the following primary fact is proved: that fact is that the person has provided property to another, not as a gift or as an advancement. For example, where Emma has contributed to the purchase of a property in Tom's name, if it can be shown that money provided by Emma was just a gift or a loan to Tom, the presumption that Emma received a beneficial interest in the property will be rebutted and no resulting trust will be inferred.

Indeed, as a true presumption, a resulting trust arises from the proof of the primary facts. In Gissing v Gissing (1971) AC 886, Violet and Raymond Gissing were a married couple and the family home was in Raymond's name, He took out a mortgage to pay for it and also had a loan from his employers. Violet's contributions were $£ 220$ from her savings to pay for a lawn and furniture. Later on she contributed from her earnings to the housekeeping and paid for her own and her son's clothes. In 1961, Raymond left Violet for a younger woman. Violet alleged that he told her "Don't worry about the house: it's yours." Later Raymond lost his job and wanted to sell the house and Violet claimed that she owned a share of it. In this case, the wife must advance material evidences on the facts of her contributions to the property to justify the court in imposition of a resulting trust. But the wife "has made no initial contribution to the cash deposit and legal charges and no direct contribution to the mortgage installments nor any adjustment to her contribution to other expenses of the household which it can be inferred was referable to the acquisition of the house” [41], her limited, indirect, financial contributions were not enough to gain a share by giving rise to a resulting trust.

In Hodgson v. Marks (1971) 1 QB 234 (CA), an elderly homeowner, Mrs Hodgson, decided to take in a lodger for company and to help out with payment of the household bills. Mr Evans moved in and had soon found his way into Mrs Hodgson's confidence, making himself useful around the house and looking after her financial affairs for her. Mrs Hodgson's relatives were suspicious of Mr Evans's motives and tried to persuade Mrs Hodgson to ask Mr Evans to leave the house. Mrs Hodgson paid no attention to their advice, however, and eventually, 
under continual pressure from her relatives and fearing that they would find a means of removing Mr Evans from the property, took the rather drastic step of conveying the property into Mr Evans's name on the understanding that she would remain the beneficial owner of the property. Unfortunately the relatives' suspicions were well founded and Mr Evans subsequently purported to sell the property to a third party, Mr Marks, without Mrs Hodgson's knowledge. The primary fact is that the transfer had clearly never been a gift to her lodger. The fact showed that Mrs Hodgson provided that property, but not as a gift and Mr Evans could not present the opposing evidence. As such, the court held that there was a clear resulting trust in favour of Mrs Hodgson.

\subsubsection{A Legal Presumption}

Legal presumptions are not necessarily the result of a process of logical reasoning, such as the presumption of death, only if the primary facts can be proved. So is the presumption of a resulting trust. As a legal presumption, the presumption of the resulting trust needs to be proved by a claimant with the primary fact that the transfer or contribution was made to the benefit of the defendant that is a fixed and uniform condition. Tinsley v Milligan (1994) 1 AC 340 taken for example, two women purchased a home as co-habiting lovers, by mutual agreement, the property was registered in Ms Tinsley's name as the sole proprietor so as to enable Ms Milligan to make false social security claims, thereby benefiting both parties. On the breakdown of their relationship, Ms Milligan counterclaimed for an order for sale claiming that the house was held on trust for both of them equally. The House of Lords held 3:2 that the defendant could nonetheless establish her interest by way of the presumption of resulting trust. Due to the fact, as a fixed and uniform condition, that Ms Milligan made a direct contribution to the purchase price, she acquired an equitable proprietary interest by the presumption of a resulting trust. And Lord Browne-Wilkinson explained: If the plaintiff proves that the property is vested in the defendant alone but that the plaintiff provided part of the purchase money, or voluntarily transferred the property to the defendant, the plaintiff establishes his claim under a resulting trust unless either the contrary presumption of advancement displaces the presumption of resulting trust or the defendant leads evidence to rebut the presumption of resulting trust.

It is a well-established principle of equity that , in the absence of a contrary evidence, where property is purchased in the name of some other person it will be held on a resulting trust for the person who has paid for the purchase. In Bull v Bull (1955) 1 QB 234 (CA), Mrs Bull and her son bought a property at 101 Rishden Gardens, Ilford, Essex in 1949. Both mother and son contributed to the purchase price for the property, but the son provided the greater part of the money and the property was conveyed into his sole name. In April 1953, the son married and it was arranged that his mother should keep two rooms in the house whilst he and his wife would have the rest. Soon afterwards, however, differences arose between the mother and her daughter-in-law and the son told his mother to leave the house. The mother contended that, despite the house being in her son's sole name, she had a right to live in the property by virtue of her contribution to the purchase of it. The court agreed, finding that she had not made a gift of the purchase money to her son and that there was therefore no presumption of advancement, but rather that there should be a resulting trust imposed in her favor. In making his judgment Lord Justice Denning confirmed that, whilst the son was undoubtedly the legal owner of the house, the mother and son owned the house together in equity. The mother was therefore entitled to a share of the house proportionate to her contribution to the purchase price.

Accordingly, in the situation of purchase of property in another's name, the presumption of resulting trusts is based on the facts of the initial contributions to the purchase of the property. In Burns v. Burns (1984) Ch 317, a couple Valerie and Patrick Burns, who had lived together for almost 20 years and who had children together, although they were not actually married. The house they lived in was paid for by Patrick with part cash and part mortgage. The mortgage was paid off with Patrick's earnings while Valerie stayed at home to look after the house and children. When Valerie returned to work she used her own earnings to buy furniture, fixtures and fittings for the house and did some painting and redecoration, although her money was not needed to pay for any of the household expenses. The relationship broke down and Patrick sought a declaration as to whether Valerie had a beneficial interest in the house. The Court of Appeal held that Valerie had no interest in the house: she had made no contributions referable to the acquisition of an interest in the property. The fact that the relationship had lasted 19 years was irrelevant in claiming an interest in the property under a resulting trust. In the situation of purchasing in another's name, the primary fact of financial contribution must be proved, which is a fixed and uniform condition in this circumstance. In this case, general child-rearing and household tasks do not count as the equivalent of a financial contribution, no resulting trust arose. 
In a word, where a property is taken in another's name alone, if one makes on "real " or "substantial” financial contribution towards either the purchase price, deposit or mortgage installments by means of which the family home was acquired, then she or he is not entitled to any share in the beneficial interest in that home even though she or he was maintaining the family, decorating the house, laying a patio, keeping house, improving the house, giving birth to and looking after and helping to bring up the children.

Nonetheless, in certain situations, if the parties stand in certain relationships the presumption of resulting trust is replaced by the presumption of advancement. In the situation of purchase of property in another's name where certain relationships exist between the transferor and the transferee, such as a husband and a wife or a father and children, the presumption of advancement [42] displaces the presumption of resulting trusts.

In Bennet v. Bennet (1879) 10 Ch D 474, a mother Ann Bennet, transferred the sum of $£ 3000$ to her son, Philip Bennet, who was in financial difficulty. Philip subsequently went bankrupt, and the trustee in bankruptcy claimed what was left of the money. Mrs Bennet's lawyers claimed that there was no presumption of advancement in this case, it being a case of loan between mother and son, and that the money should be returned to her as it was held by her son for her on a resulting trust. The court upheld the mother's claim, in any event, there was evidence in this case that mother transferred the money as a loan, not as an advancement.

Certainly, in respect of married couples, the position has been somewhat alleviated by section 37 of the Matrimonial Proceedings and Property Act of 1970, which states that: Where a husband or wife contributes in money or money's worth to the improvement of real or personal property in which or in the proceeds of sale of which either or both of them has or have a beneficial interest, the husband or wife so contributing shall, if the contribution is of a substantial nature and subject to any agreement to the contrary express or implied, be treated as having then acquired by virtue of his or her contribution a share or an enlarged share, as the case may be, in that beneficial interest. But this section does not assist unmarried couples. Thus, in Burns v Burns, Valerie was not entitled to bring proceedings under the matrimonial legislation because they were unmarried.

In Stack v Dowden (2007) 2 All ER 929, Baroness Hale based her arguments on the maxim that equity follows the law. So that where the legal ownership is in joint names, the presumption is that the beneficial interest will also be jointly owned.

To sum up, the primary facts are regarded as an evidential vehicle for the imposition of a resulting trust by the court. The transferring of the property is conceived as a fact which, along with others, calls for the creation of rights by operation of law. The primary fact is that the transferring of the property should not be subject to a gift by imposing a resulting trust, which is the fixed and uniform condition from which a resulting trust arises save the opposing evidences to the fact.

\section{Presumption's Rebutting by Evidential Circumstances}

\subsection{The General Survey of the Content Presumed and Rebutted}

A legal presumption can be rebutted by evidential circumstances. Take the presumption of death for example, can be rebutted in case that the other party is able to adduce some evidence that the person is still alive. In this scenario, the content of presumption which will be rebutted is "death" and "The person is still alive" is the evidential circumstances. In the scenario of the order of seniority, in light of the provision of S.184 of the Law of Property Act 1925 that where two or more persons have died in circumstances rendering it uncertain which of them survived the other, such deaths shall be presumed to have occurred in order of seniority, and accordingly the content of the presumption is that the younger shall be deemed to have survived the elder, which can be rebutted only when the fact that the elder had survived the younger can be proved.

As to the resulting trusts, the content of the presumption is that a resulting trust arises in the first place from the gratuitous or voluntary transfer or purchase of property in another's name or joint names in the absence of clear evidence to the contrary. Because equity presumes that the property belongs to the person who advances the purchase money, that is, in the absence of evidence to rebut the presumption. Thus, the presumptions of resulting trust are assumptions that the ownership of beneficial interests belongs to the providers.

The presumption of a resulting trust is a prima facie rule of evidence which is capable of being rebutted. In the situations of the gratuitous or voluntary transfer or purchase of property in another's name or joint names, equity prima facie considers the transferee as a trustee for the transferor. The transferor is presumed to have retained the beneficial interests and the transferee is presumed to obtain a nominal interest in the property. The presumed consequence of the resulting trusts can be prevented from materializing in appropriate circumstances. 
In other words, if there is other evidence, the courts will look at that evidence and may come to a different conclusion. The presumption is subject to evidence to the contrary, that is, it can be rebutted by the facts of indeed a gift, a loan and it can also be replaced by the presumption of advancement [43]. The function of the presumption of a resulting trust is to put a rule into place by the courts in a bid to protect the more vulnerable against those who would take advantage of them [44].

What counts as evidence in consistent with the presumption of a resulting trust? In line with the two schools of thoughts mentioned above, the content of presumption rebutted is different. On the view of "SwadlingBrowne Wilkinson" school, where one gratuitously transfers property to the other, the presumption is that one intended the other to hold that property on trust for him. On this basis, unless the presumption is rebutted, a resulting trust arises to give effect to one's intention. On the view of "Birks-Chambers" school, in such situations it is presumed that one did not intend the other to take the property beneficially, unless non-beneficial intention is rebutted. In the situation that one transfers property to the other wrongly believing he owes to the other, the two schools have quite different outcomes to whether a resulting trust arises. In fact, since the other gives nothing in return for the money, the presumption of resulting trust is definitely imposed. But on the first view, the presumption depends upon one' intention to create a trust in his favor, which will be rebutted by the fact that one is intending to discharge a debt that he wrongly believes he owes to the other. Therefore, no resulting trusts will arise. By contrast, on the second view, the presumption depends on non-beneficial intention, which can not be rebutted by the fact that one is intending to discharge a debt that he wrongly believes he owes to the other, a resulting trust irrebuttably arises. In Westdeutsche Landesbank Girozentrale v Islington London Borough Council (1996) AC 669, the claimant bank paid significant sums of money to the defendant local authority under a contract which turned out to be void since it was beyond the powers of the local authority. When this was discovered, the bank argued, inter alia, that there was a resulting trust of the money it had paid to the authority under the void contract. Since the contract had no legal effect, nothing had been given in return for the money, hence the presumption of resulting trust was raised. However, on the view that the presumption was of a lack of intent to benefit the transferee, this had not been rebutted, since the bank did not intend the authority to have the money in the circumstances.

As mentioned above, the presumption of resulting trust is irrelevant to the intention of parties. The presumption of resulting trust is just that the transferee is presumed to hold the property on trust for the transferor or the purchaser, which is occasionally displaced by evidence of the contrary facts or a counter-presumption of equity. Thus, in the situation of a contribution to the purchase price of property, where there is evidence that money was provided by way of loan, there can be no room for the presumption of resulting trust.

The upshot of this can derive some support from the case of Vandervell v IRC (1967) 2 AC 291, in 1958 Vandervell wished to found a Chair in Pharmacology at the Royal College of Surgeons. He planned to transfer shares in Vandervell Productions Ltd to the College, in whose favor dividends on the shares would subsequently be declared. As a charity, the College enjoyed fiscal privileges, the attraction of the transaction being that the dividends would not give rise to tax liability. The shares were to be transferred subject to the option to repurchase in favour of Vandervell Trustees Ltd, a company administering trusts connected to Vandervell's family and business enterprises. Once the dividends were paid, the shares could be retrieved by Vandervell Trustees Ltd. Vandervell was sure that if the option was not vested in him he could avoid any liability for tax. Until 1961, the College was in receipt of dividend payments on the shares. The Inland Revenue sought to claim surtax on the dividends, arguing that Vandervell had failed to declare a trust of the option, the benefit must be held on resulting trust for Vandervell. In this case, because of a lack of the necessary evidence, the resulting trusts which followed is not in any way a reflection of any intention of Mr Vandervell. The fact is that Mr Vandervell could not actually have had any such intention, which can be proved by the clear evidence. But the presumption is made from some facts which sometimes need be evidenced. The evidences to the contrary can rebut the facts for presumption. The evidential circumstances of the actual case can rebut the initial conclusion of the presumption by operation of law.

\subsection{Evidential Circumstances of Rebutting}

The presumption of a resulting trust can be rebutted by the strength evidences adduced. The presumed resulting trust arises from numerous fact situations which are actually very diverse, thereupon the evidential circumstances of rebutting the presumption are also diverse, but they can be classified into the following types. 


\subsubsection{Voluntary Transfer to Another}

The presumption of a resulting trust from a voluntary transfer to another can be rebutted by the evidence in favor of a gift.

In Fowkes v Pascoe (1875) LR 10 Ch App 343, the court held that, though the presumption of resulting trust applied, it was clearly rebutted by the fact that there was simply no plausible explanation for the purchase except that Mrs Baker made a gift of the stock to Pascoe, the circumstances and the relationship between the parties taken into consideration. As James LJ put it:

The evidence in favor of gift and against trust is absolutely conclusive... The lady had $£ 500$ to invest; she had already large sums of stock standing in her own name, besides other considerable property. Is it possible to reconcile with mental sanity the theory that she put $£ 250$ into the names of herself and her companion, and $£ 250$ into the names of herself and [Pascoe], as trustees upon trust for herself?

In this case, on the evidence provided to the court it was held that the money was indeed a gift, and the presumption of a resulting trust was rebutted. However, had there been no substantial evidence to prove this, a resulting trust would certainly have been imposed.

In Re Vinogradoff (1935) WN 68, the court held that the money should be held on resulting trust for the estate of Mrs Vinogradoff, there being no evidence of a gift to rebut the presumption of a resulting trust.

In Walker v Walker, the public declaration by a father that he just gave his newly wedded son the money to set up a home was sufficient to show that he benefited his son by way of gift. Just as Browne-Wilkinson L.J. said, "Once ... the father had said that he was making a gift to the son, any claim based on the resulting trust must fail” [45]. Therefore, the gift can be the evidential circumstance to rebut the presumption of voluntary transferring resulting trust.

In Boyce v Boyce (1849) 6 Sim. 476, A testator left his three houses to his widow and further instructed her to give one house to Maria (his daughter), whichever one Maria chose, and the remaining 2 houses to Charlotte. However, Maria died before choosing the house. Consequently, the houses were held on resulting trust for the testator's residuary estate. The rebutting evidence is that the fact of the selection of the house before death, but it's impossible.

\subsubsection{Purchase in the Name of Another}

The principle of "he who pays, owns" [46] is important in arising as to the situations of purchase in the name of another or joint names. It is assumed that neither party made a gift of their contribution to the purchase price, which can be rebutted by the evidence to the contrary. Here the resulting trust is presumed to arise in the absence of evidence to the contrary or rebutted by the contrary evidences.

In the Venture (1908), a resulting trust is presumed depending upon the bare fact of Percy's contribution with nothing establishing on the evidence. But the presumption of the resulting trust can be displaced by the other party's offering the contrary evidences.

In Laskar v Laskar (2008) EWCA Civ 347, (2008) 1 WLR 2695 a mother and daughter bought a house together, which they let to tenants. The value of the house was $£ 79,500$ but it was bought at a discount of $£ 50,085$ as a result of the mother’s previous occupation of it as a secured tenant. The daughter paid £3400, £43,000 came from a mortgage loan, and the mother paid the remainder. The mortgage was paid from rental income which was paid to the mother. The daughter claimed a joint beneficial interest in the property. It was held that, where members of a family purchased property in their joint names, there was a presumption of equal interest following Stack v Dowden, but this did not apply where the property was purchased as an investment when the beneficial interest would reflect their respective contributions to the purchase price by virtue of a resulting trust analysis. Consequently, the mother's discount was reflected in her interest. Since the mortgage loan was taken out in their joint names and they were jointly and severally liable for repayment they had an equal interest to the extent of the mortgage loan. It was not argued that the presumption of advancement applied, and the Court suggested that that was correct, apparently because the daughter was over 18 and managed her own financial affairs. The court concluded that the daughter should have a one-third beneficial interest and this was considered to be a fair result in the absence of evidence to the contrary.

\subsubsection{Fund Surplus}

In the case of non-charitable fund surplus, the presumption of a resulting trust for the donors or subscribers or contributors can be rebutted by the evidence to the contrary.

In the case of Re Abbott fund (1900) 2 Ch 326 (ChD), a fund to support two elderly women was raised by 
their friends and relatives. After both had died, it was not clear how to distribute the surplus money, which was a substantial sum. The fund could have been construed as a gift to the women, in which case the surplus would have gone to their estates. However, Stirling J. decided that there was no evidence that this is what the donors intended, and that the surplus should be held for them on resulting trust.

Re Gillingham Bus Disaster Fund (1958) Ch 300, a fund was raised to pay for funeral expenses, etc., of a group of army cadets who had been killed in a bus crash. Since the families of the cadets had private-law actions against the bus company, the amount raised was far in excess of what was required. The question then arose how to distribute the surplus. Harman J followed the decision of Re Abbott (1900), which had held that the surplus of a non-charitable benevolent fund should be held on trust for its subscribers. Since the bulk of the money in Gillingham had been raised by donations from the public, it would clearly be very difficult to return the surplus. However, there was no doubt that in principle a resulting trust could be imposed on the surplus in favor of the subscribers except for the contrary evidence. And so it was.

In re west sussex constabulary widows fund (1971), although the general principle-that surplus funds should be returned to subscribers - was upheld, the Court of Appeal declined to rule that funds raised from public donations should be held on trust for the public donors. The Court doubted that Gillingham should really be read as imposing such a requirement anyway. Where the contributions were from specific, identifiable bequests, then the surplus would be held on resulting trust for the donors' estates.

In the case of Re Bucks Constabulary Fund (No. 2), the fund, which was registered under the Friendly Societies Act 1896, was made up of voluntary contributions from its members, for the relief of widows and orphans of deceased members of the Bucks Constabulary. Under s.49(1) of the 1896 Act, property belonging to a registered friendly society was vested in trustees for the benefit of the members and those claiming through them. There was no provision for distribution of the assets of the fund in the event of the society being wound up.

In April 1968 the Bucks Constabulary was amalgamated with other constabularies to form the Thames Valley Constabulary, and in October 1968 the society was wound up. The trustee applied to court to determine how the funds were to be distributed.

The surplus assets were held on trust for the members of the society at the time of its dissolution, to be distributed among them in equal shares.

Air Jamaica v Charlton (1999) 1 W.L.R. 1399, When a company pension fund was wound up, its contributors argued for a return of their outstanding contributions, even though they had received their expected entitlement. The argument, in a sense, was the long-standing one about what should happen to the surplus funds of an unincorporated association when it is dissolved. Because the contributors had been paid off in full, it was argued for the Crown that the surplus money was Bona vacantia.

Lord Millet stated that, although the prevailing view is that the surplus funds of an unincorporated association were not required to be returned to their contributors (e.g., Re West Sussex Constabulary Widows Fund (1971)), where there is a small number of well-defined contributors it is just to return their excess contributions.

It was suggested that the mechanism to give effect to this decision was to find that a resulting trust arose in favor of the contributors, with the association members as its trustees. Although many academics (notably Birks and Chambers) have argued for an expanded role of resulting trusts in restitution, this view has not found favor with the House of lords in recent years (see West Deutsche v Islington 1996), and this part of the judgment may have to be regarded as out of line with prevailing authorities. However, if a resulting trust is not the right mechanism to give effect to the decision that the unincorporated association holds its surplus funds on trust for its contributors, it is not clear what else is.

\subsubsection{Presumption of Advancement}

In some situations where equity recognizes that there is an obligation of conscience owed by the transferor "to advance" or to support the welfare of the transferee, there is no presumption of resulting trust because the transferor is presumed to transfer the property freely to the transferee on account of the relationship of obligation. Where the presumption of advancement applies, it effectively reverses the presumption of resulting trust, in that equity presumes that a gratuitous transfer from one to the other takes effect as a gift rather than a trust. Section 60(3) of the Law of Property Act 1925 provides: In a voluntary conveyance a resulting trust for the grantor shall not be implied merely by reason that the property is not expressed to be conveyed for the use or benefit of the grantee. 
In Murless v Franklin (1818) 1 Swans 13 at 17, Lord Eldon described the duty to advance as being a, "species of natural obligation to provide...”. In Goodfriend v. Goodfriend (1972) 22 D.L.R. (3 rd) 699 at 703, Spence J. explains, "to make a gift of the subject matter of the transfer to the transferee".

This presumption arises when certain relationships exist between the transferor and the transferee. The relevant relationships involve a moral obligation on the part of the transferor towards the transferee .Transfers give rise to the presumption include father to legitimate child and husband to wife.

If the transfer took place before s 199 of the Equality Act 2010 comes into force, where the transferor was the father of the transferee or the husband of the transferee or stood in loco parentis to the transferee the presumption of resulting trust was replaced by the presumption of advancement [47].

In McGrath v Wallis (1995) 2 FLR 114, a house was acquired for joint occupancy by a father and son in the sole name of the son. The purchase price was provided partly by proceeds of sale of the father's previous house and partly by means of a mortgage. There was no evidence that the father made a gift of the house to his son. On the basis of all the surrounding circumstances, the Court of Appeal held that the presumption of advancement was rebutted, and that the father acquired an 80 percent interest in the property by way of resulting trust. They were readily rebutted by comparatively slight evidence.

In Warren v Gurney (1944) 2 All ER 472, a father purchased a house in the name of his daughter prior to her wedding. He retained the title deeds until his death. The Court of Appeal held that the presumption of advancement was rebutted by evidence that the retention of the title is not a gift, not as an advancement.

In Re Gooch (1890) 62 LT 384 Sir Daniel Gooch transferred shares into the name of his eldest son. The son paid the dividends from the shares to his father, who also retained the share certificates. Kay $\mathrm{J}$ held that the presumption of advancement was rebutted by evidence that the shares had been transferred to qualify the son to become a director of the company, and that no gift had been made.

In Simpson v Simpson (1992) 1 ELR 601, a husband transferred his bank account into the joint names of himself and his wife. The property was held, after his death, by his wife on resulting trust for his estate, which can be rebutted by the fact that the husband did make a gift.

\section{Conclusion}

Both schools of thoughts on the nature of the presumed resulting trusts claim that resulting trusts give effect to the presumed intention, positive or negative. In fact, what is given effect is equity's imputation of a legal result. In some circumstances, equity does not recognize an effective disposition of property, but instead imposes a resulting trust by operation of law. Moreover, there seem to be a handful cases in which resulting trusts have been found which can not be explained on the basis that the presumption is a lack of intent to benefit or a positive intent to create a trust. Neither a lack of intent to benefit nor a positive intent to create a trust is related with the presumption of the resulting trusts.

\section{References}

[1] See Westdeutsche Landesbank Girozentrale v Islington LBC (1996) AC 669,708. See Swadling, “A Hard Look at Hodgson v Marks”, Rickett and Grantham, "Resulting Trusts-A Rather Limited Doctrine”, Payne, “Quistclose and Resulting Trusts”. Peter Birks and Francis Rose, Restitution and Equity, Vol. I, Mansfield Press, 4.

[2] Birks and Chambers, etc. (1997) Hold This Restitutionary View. “All Resulting Trusts Come into Being Because the Provider of Property Did Not Intend to Benefit the Recipient.” See Chamber, R., Resulting Trusts, Oxford.

[3] Ramjohn, M. (1995) Sourcebook on Law of Trusts. Cavendish Publishing Limited, London, 201.

[4] Ramjohn, M. (1995) Sourcebook on Law of Trusts. Cavendish Publishing Limited, London, 241.

[5] Swadling, W. (1996) A New Role for Resulting Trusts. Legal Studies, 16, 110-131. http://dx.doi.org/10.1111/j.1748-121X.1996.tb00402.x

[6] Westdeutsche Landesbank Girozentrale v Islington London Borough Council (1996) AC 669 AT 708.

[7] Standing v Bowring (1885) 31 Ch D 282 at 289.

[8] Hudson, A. (1999) Principles of Equity and Trusts. Cavendish Publishing Limited, London, 53-54.

[9] Penner, J.E. (2008) The Law of Trusts. 6th edition, Oxford University Press, Oxford, 87.

[10] Swadling, W. (2008) Explaining Resulting Trusts, LQR 72-80.

[11] (1908) The Venture. 218. 
[12] (1908) The Venture. p. 230.

[13] Mowbray, W.J. (1964) Lewin on Trusts. 16th Edition, Sweet \& Maxwell, London, 8.

[14] (2000) Trusts Which Are Inferred from Doubtful Words, for Example, (Sometimes Called "Precatory Trusts”) Are Therefore Express, Declared Trusts. In Such Circumstance, the Court Construes the Evidence Available and Concludes That the Settler Sufficiently Manifested an Intention to Declare the Trust. In: Birks, P. and Rose, F., Eds., Restitution and Equity, Vol. 1, Mansfield Press, Toronto, 8.

[15] Pettitt v Pettitt (1970) AC 777,823; Murphy and Deane JJ. Further the Discussion In Calverley v Green (1984) 155 CLR 242,264-266.

[16] Clements, R. and Abass, A. (2011) Equity and Trusts. Oxford University Press, Oxford, 329.

[17] Milligan, T. (1994) 1 AC 371.

[18] Penner, J.E. (2008) The Law of Trusts. 6th Edition, Oxford University Press, Oxford, 90.

[19] Dyer v Dyer (1788) EWHC Exch J8, 2 Cox Eq Cas 92.

[20] Vandervell v Inland Revenue Commissioners (1967) 2 AC 291.

[21] Panesar, S. (2010) Exploring Equity and Trusts. Pearson Education, Limited, Upper Saddle River, 277.

[22] Chambers, R. (1997) Resulting Trusts. Clarendon Press, Oxford, 34.

[23] Chambers, R. (1997) Resulting Trusts. Clarendon Press, Oxford, 35.

[24] Simpson, E. (2000) On the Nature of Resulting Trusts: The Vandervell Litigation Revisited. In: Birks, P. and Rose, F., Eds., Restitution and Equity, Vol. 1, Mansfield Press, Toronto, 21.

[25] Vandervell v IRC (1967) 2AC 313.

[26] Vandervell v IRC (1967) 2AC 329.

[27] Chambers, R. (1997) Resulting Trusts. Clarendon Press, Oxford, 52.

[28] Westdeutsche Landesbank Girozentrale v Islington LBC (1996) AC 706.

[29] Taylor, A. (2000) Principles of Evidence. Cavendish Publishing Limited, London, 39.

[30] Nokes, G.D. (1967) An Introduction to Evidence. 4th Edition, Sweet \& Maxwell, London, 74.

[31] Murphy, P. and Glover, R. (2011) Murphy on Evidence. 12th Edition, Oxford University Press, Oxford, 686-687.

[32] Durston, G. (2011) Evidence Text and Materials. 2nd Edition, Oxford University Press, Oxford, 143.

[33] Phipson (2005) On Evidence. 16th Edition, Sweet \& Maxwell, London, 136.

[34] Murphy, P. and Glover, R. (2011) Murphy on Evidence. 12th Edition, Oxford University Press, Oxford, 73.

[35] Cooper, S., Murphy, P. and Beaumont, J. (1997) Cases and Materials on Evidence. 4th Edition, Blackstone Press Limited, Bondi Junction, 72.

[36] Phipson (2005) On Evidence. 16th Edition, Sweet \& Maxwell, London, p. 136.

[37] Thomas, G. and Hudson, A. (2010) The Law of Trusts. Oxford University Press, Oxford, 728.

[38] Haley, M. and McMurtry, L. (2011) Equity \& Trusts. Sweet \& Maxwell, London, 297-306.

[39] Swadling, W. (2008) Explaining Resulting Trusts. Law Quarterly Review.

[40] Bagshaw, R. and Cross, R. (1996) Outline of the Law of Evidence. Butterworths, London, 37.

[41] Gissing v Gissing (1971) AC 886 at 909.

[42] The Presumption Will Be Abolished by s 199 of the Equality Act 2010 for All Transfers etc. Made after the Section Comes into Force.

[43] The Presumption Which Runs Contrary to the Presumption of a Resulting Trust Is That People in Some Certain Relationships Will Be Presumed, Subject to the Presentation of Evidence to the Contrary, to Have Made an Outright Gift to the Recipient. Therefore, in Such Situations There Will Be No Presumption of a Resulting Trust Arising in Favour of the Grantor. If the Transfer Was Made before s 199 of the Equality Act 2010 Comes into Force.

[44] Warner-Reed, E. (2011) Equity and Trusts. Pearson Education Limited, Upper Saddle River, 176.

[45] Haley, M. and McMurtry, L. (2011) Equity \& Trusts. 3rd Edition, Sweet \& Maxwell, London, 309.

[46] Duddington, J. (2006) Essentials of Equity and Trust Law. Pearson Education Limited, Upper Saddle River, 159.

[47] Edwards, R. and Stockwell, N. (2011) Trusts and Equity. 10th Edition, Pearson Education Limited, Upper Saddle River, 253. 